Egyptian J. Anim. Prod.,Vol. 31,Supplement Issue, Nov.(1994):121-133.

\title{
PROCESSING AND FEEDING VALUE OF POULTRY MANURE AS A FEED INGREDIENT FOR SHEEP
}

\author{
H.M. El Shaer, S.A. Attia-Ismail and H.M. Kandil \\ Department of Animal and Poultry Nutrition, Desert \\ Research Center, Mataria, Cairo, Egypt
}

\section{SUMMARY}

Two experiments were conducted to evaluate the effects of various treatments of poultry manure on energy and nitrogen losses and the control of pathogens; and to asses the fermentation characteristic and feeding values of different ratios of bermudagrsss hay and poultry manure silages (BGH-PM silages). Results of the first experiment showed that ensiling process had the least nitrogen and energy losses and was free of pathogens. In feeding and metabolism trials, 32 sheep were divided into four groups assigned to four diets: $100 \%$ bermudagrass hay (TI) as a control treatment, the other diets were silages (BGH-PM silage) contained 70:30. (T2), $60: 40$ (T3) and 50:50 (T4) bermudagrass hay and poultry manure. DMI and nitrogen retention values were highest for sheep fed 70:30 BGH-PM silage compared to the other treatments. All apparent digestion coefficient of nutrients were improved by increasing proportion of poultry manure in silages. The tested liver function enzymes of sheep were in clinical normal ranges.

Keywords: Poultry manure, excreta processing, sheep, feed value, rumen metabolites, blood metabolites

\section{INTRODUCTION}

Nowadays, there has been tendency, in Egypt, to increase cultivable lands in order to produce more grains for human consumption at the expense of the production of forages for animal feeding. Therefore, the 


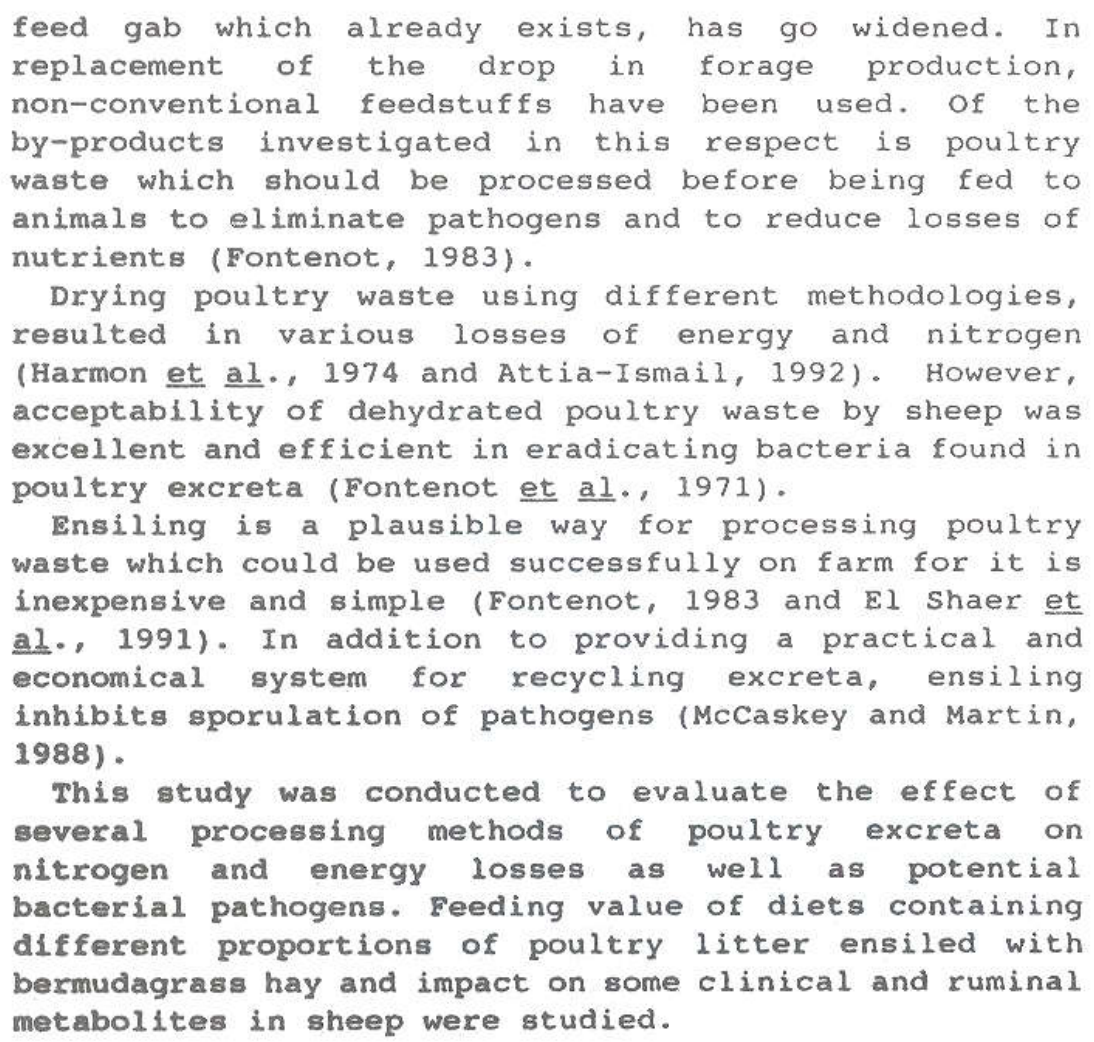

Ensiling is a plausible way for processing poultry waste which could be used successfully on farm for it is inexpensive and simple (Fontenot, 1983 and El shaer et al., 1991). In addition to providing a practical and economical system for recycling excreta, ensiling inhibits sporulation of pathogens (McCaskey and Martin, 1988).

This study was conducted to evaluate the effect of several processing methods of poultry excreta on nitrogen and energy losses as well as potential bacterial pathogens. Feeding value of diets containing different proportions of poultry litter ensiled with bermudagrass hay and impact on some clinical and ruminal metabolites in sheep were studied.

\section{MATERIAIS AND METHODS}

Two experiments were involved in this study. The first one was conducted to determine the effect of various treatments of poultry manure on energy and nitrogen loss, in addition to the effect on odor and pathogens. The second experiment was feeding and metabolism trials for sheep fed bermudagrass hay and its silage with poultry manure (BGH-PM silages).

The first experiment

A large quantity of fresh poultry manure from caged laying hens was thoroughly mixed and subjected to the following treatments:

1- Fresh PM, no treatment, 2- Air-drying PM at ambient temperature (28-300C) 3- Solar drying at 60-70 oC to a constant weight, 4- sun drying/autoclaving at $1.0 \mathrm{~kg} / \mathrm{cm} 2$ 
at 120 oC., 5- Oven drying at 60 oc for 24 hrs., 6-Oven drying at $100 \mathrm{oC}$ for $24 \mathrm{hrs}$. and 7 - Ensiling chopped bermudagrass hay (BGH) and PM at different proportions of $70: 30,60: 40$ and $50: 50$, respectively.

\section{silage making}

Bermudagrass hay (IFN 1-00-716) was chopped $(2-5 \mathrm{~cm}$ length), ensiled with caged layer manure (BGH-PM silage) in the following ratios on wet basis: $70: 30,60: 40$ and 50:50. Weighed quantities, in proportions according to the above mentioned ratios, of the fresh poultry manure and bermudagrass hay, mineral and vitamin mix and little quantity of water were mixed thoroughly and ensiled carefully in huge plastic drums (three replicates for each silage). The silos were, opened after 45 days and silage samples were collected for subsequent analysis. physical and fermentative characteristics, (pH, lactic acid, water soluble carbohydrates and volatile fatty acids) were determined in six samples for each silage.

The losses of energy and nitrogen. were determined, in the fresh and treated samples ( 6 samples for each treatment) by difference. The nitrogen contents were determined by Kjeldahl method. Energy values were, also estimated using benzoic acid (Shannon and Brown, 1969). Microbial counts [standard plate count (SPC)] and coliform count were made by the standard methods (the American Public Health Association, 1978).

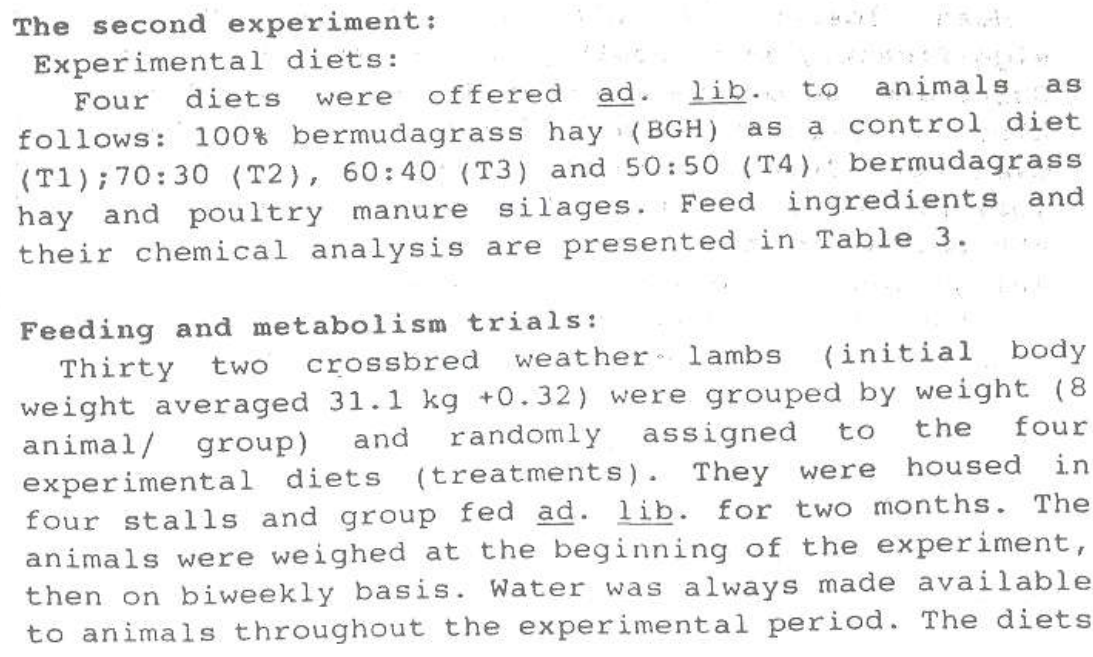


were offered to animals daily at 0800 and $1700 \mathrm{~h}$, and residues were weighed the next morning at 0700 .

At the end of the feeding trial ( 2 months), four animals were randomly chosen from each treatment (group) and placed in metabolism cages for a 7-day preliminary period followed by a 7-day collection period. Feces and urine were collected daily, sampled and recorded. Representative samples of the four diets and rots as well as feces were taken daily and dried and saved for coltine analysis (A.O.A.C., 1975). At the end of the using stomach were collected 2 hrs after feeding. Blood samples rumen liguor 2 hrs post feeding simultaneously with analyzed for collection. Rumen liquor samples were Schoeman, 1964) pH, ammonia-nitrogen (Schwartz and and Reid, 1956). Blood samplatile fatty acids (Barnett urea nitrogen (Clood samples were analyzed for blood oxaloacetic (Coulombe and Larreau, 1963). Glutamic transaminase (GPT) (GOT), glutanic pyruric alkaline phosphat), gama glutamine transferase (GGT) and and Frankel. 1957). (ALP) were also determined (Reitman statistical analysis was done (1955).

\section{RESULTS AND DISCUSSION}

Processing poultry manure as feed ingredients

Mean losses of nitrogen and energy differed significantly among poultry manure treatments (Table 1). Solar dry, autoclave and oven dry (600C) treatments were oven dry percent losses of both nitrogen and energy. loss (5.958) than even that showed the highest nitrogen attributed fresh manure. It could be attributed to the excessive evaporation. The maximum energy loss value was achieved using the fresh manure without any processing (8.398). Similar trends were obtained by many workers. (Shannon and Brown, 1969 and Harmon et al., 1974). Ensiling poultry manure process showed the lowest energy and nitrogen losses.

Various treatments of poultry manure resulted in variable degrees of odor in the materials (Table in Autoclaving and ensiling treatments produced the least odorous materials. Salmonella, Escherichia coli and Staphylococcus were totally eliminated by any of the 
treatments applied to poultry manure (Table 1).

Table 1. Effect of poultry manure process on mean losses of nitrogen and energy; odor and pathogens

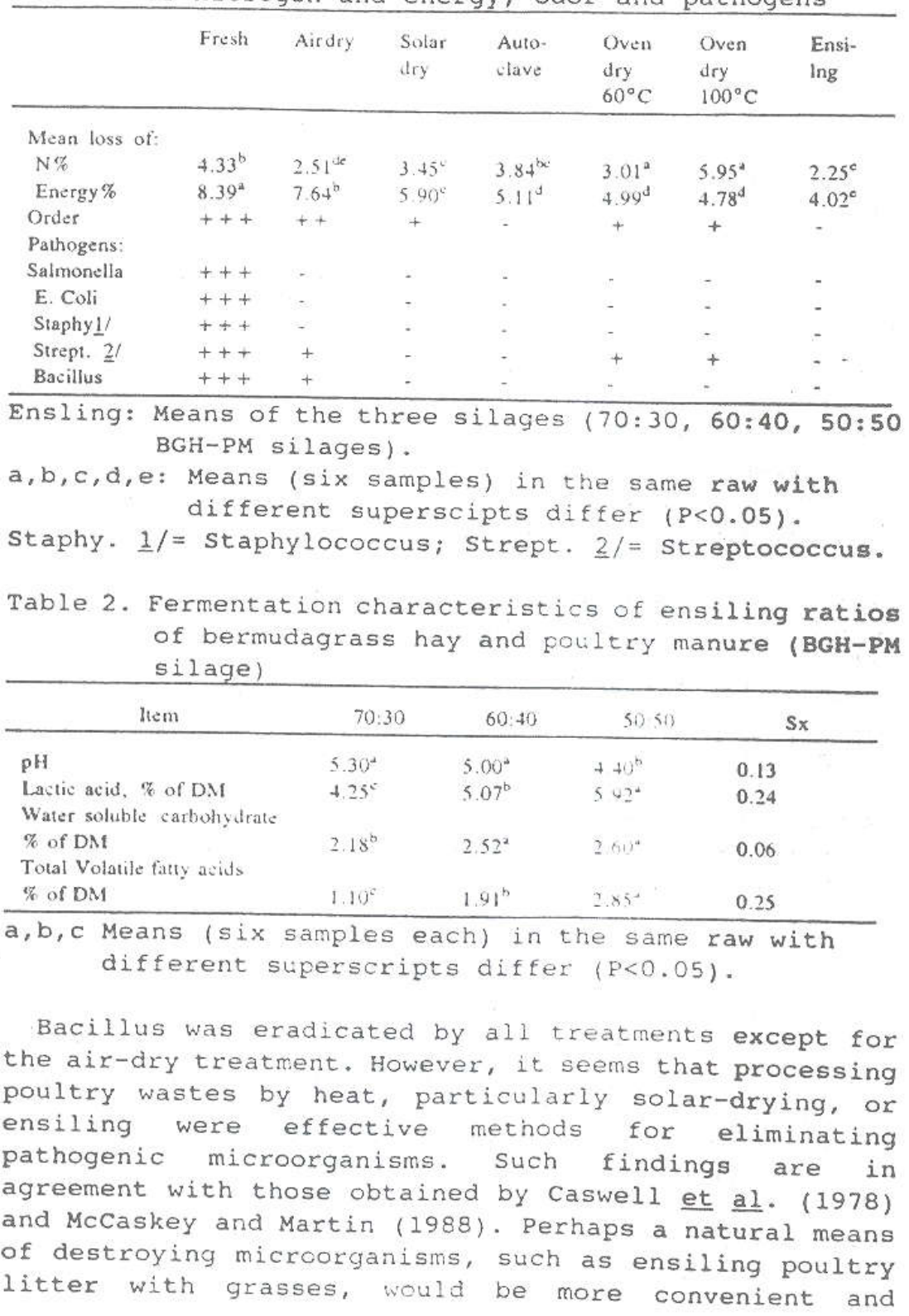


economical than the use of artificial heat. The obtained results concluded that the ensiling process seems to be a convenient method for preserving and rendering poultry manure silages safe from potentially pathogenic microorganisms.

Chemical composition of the experimental diets

The chemical composition of bermudagrass hay ( $T 1$ ) and ensiled mixtures of bermudagrass hay-poultry manure is presented in Table 3. The addition of poultry manure to bermudagrass hay (BGH) at the time of ensiling decreased the dry matter (DM) content because of the decrease in the proportion of BGH which contained high DM content $(90.5 \%)$. There was an increment in ash content (up to 12.58 ) of the silages by adding poultry manure due to higher ash content in poultry waste (Table 3). Calcium content of BGH-PM silages increased dramatically by the inclusion of poultry manure (up to 4.328), and so was phosphorus content. Poultry waste can replace mineral supplement in rations for ruminants, (Oliphant, 1974 and Fontenot, 1983). The decreased levels of $\mathrm{CF}$ as well as the increased content of $\mathrm{CP}$ in the silages were found as a result of inclusion poultry manure in the silage mixtures. These results agree with those reported by other investigators, (Oliphant, 1974, Fontenot, 1983 and El shaer et al., 1990). The diet contained 50:50 BGH:PM silage (T4) appeared to be more nutritious as it had the highest $C P$ and NFE contents $(12.7$ and $51.3 \%$, respectively) while CF content was lowest (20.1\%).

Metabolism trials

Dry matter intake (DMI) and digestibility

The voluntary DMI and digestion coefficient of nutrients data are presented in Table 4. The higher proportions of poultry manure in the silages the lower the DMI. Sheep in T2 (70:30 BGH-PM silage) and T3 (60:40 BGH-PM silage) tended to consume more ( $\mathrm{P}<0.01$ ) dry matter than those fed the control diet (bermudagrass hay, T1). Sheep in T4 (60:40) consumed the lowest ( $P$ $<0.01)$ amounts of silage $(665 \mathrm{~g} / \mathrm{head} / \mathrm{day})$. Apparent digestion coefficients of all nutrients (OM, CP, CF, EE and NFE) were significantly ( $P<0.01)$ higher for animals fed diets of $\mathrm{T} 3$ and $\mathrm{T} 4$ than those in $\mathrm{T} 1$ and $\mathrm{T} 2$ (Table 4). Therefore, the inclusion of increasing levels (up to 50\%) of the poultry manure improved the 
digestibilies of nutrients in the $B G H-P M$ silages. Such higher digest-ibility values could be attributed to the fact that poultry manure is rich in nitrogen and mineral contents and bermudagrass is rich in energy content as well. So, associative effects of ensiling such feed ingredients could be the reason for improved nutrient digestion of those diets when fed to sheep. However, there was no any digestive disturbance or palatability problems in the experimental animals. These results are in good agreement with those reported by other researchers on sheep fed poultry excreta ensiled with different feed ingredients, i.e. corn, legumes and grasses forages (Caswell et al., 1978; Fontenot, 1983, Abdelmawla et al., 1987 and El shaer et al., 1990).

Table 3. Feed ingredients and proximate compositions of diets during feeding and metabol ism trials, on OM bas is

\begin{tabular}{|c|c|c|c|c|c|}
\hline \multirow[b]{2}{*}{ liem } & \multirow{2}{*}{$\frac{\mathrm{BGH}}{\mathrm{T}_{1}}$} & \multicolumn{3}{|c|}{$\begin{array}{l}\text { BGH-PM } \\
\text { silage }\end{array}$} & \multirow[t]{2}{*}{$\begin{array}{l}\text { Poultry } \\
\text { manure }\end{array}$} \\
\hline & & $\begin{array}{c}T_{2} \\
70: 30 \\
\end{array}$ & $\begin{array}{c}T_{3} \\
60: 40 \\
\end{array}$ & $\begin{array}{c}\mathrm{T}_{4} \\
50: 50\end{array}$ & \\
\hline \multicolumn{6}{|c|}{ Chemical composition $\%$} \\
\hline DM & 90.5 & 71.50 & 65.20 & 61.90 & 30.70 \\
\hline Ash & 5.0 & 9.10 & 12.20 & 12.50 & 23.10 \\
\hline $\mathrm{CF}$ & 29.9 & 32.00 & 24.70 & 20.10 & 15.10 \\
\hline $\mathrm{CP}$ & 8.9 & 10.80 & 11.90 & 12.70 & 26.50 \\
\hline EE & 2.6 & 2.80 & 2.90 & 340 & 3.60 \\
\hline NFE & 53.6 & 45.30 & 48.30 & 51.30 & 31.70 \\
\hline $\mathrm{Ca}$ & 0.44 & 2.10 & 3.45 & 4.30 & 7.70 \\
\hline P & 0.19 & 0.93 & 1.22 & 1.41 & 3.02 \\
\hline
\end{tabular}

1/ Bermudagrass hay, coastal (Cyndon dactylon, IFN 1-00-716).

$2 /$ Mixtures of bermudagrass hay- poultry manure silages.

Nitrogen utilization

Nitrogen intake, as presented in Table 4, varied significantly among the four treatments. The low protein basal diet showed the lowest fecal and urinary nitrogen excretion due to the lowest nitrogen intake. Feeding poultry manure included in the silages resulted in higher $(\mathrm{P}<0.01)$ fecal and urinary nitrogen excretion compared to feeding bermudagrass hay (TI). However, nitrogen retention values were lowest $(P<0.01)$ for sheep fed silages contained higher proportions of poultry manure ( $\mathrm{T} 3$ and $\mathrm{T} 4$ ). It is due to lower consumption of silages, in addition to higher amounts of nitrogen 
excreted in urine and feces (Table 4). Sheep fed the $70: 30$ BGH-PM silage ( $\mathrm{T} 2$ ) retained more nitrogen than those fed the control diet ( $B G H, T 1)$. Such trends were found by Abdelmawla et al. (1987) and Kwak et al. (1987).

Table 4. Intake, digestibility and nitrogen utilization by sheep fed bermudagrass hay with poultry manure (BGH-PM silages)

\begin{tabular}{|c|c|c|c|c|c|}
\hline Item & $T_{1}$ & $\mathrm{~T}_{2}$ & $\mathrm{~T}_{3}$ & $\mathrm{~T}_{4}$ & $\overline{s x}$ \\
\hline \multicolumn{6}{|l|}{ Dry matter intake: } \\
\hline $\mathrm{g} / \mathrm{head} /$ day & $710^{b}$ & $778^{\mathrm{a}}$ & $740^{\mathrm{a}}$ & $665^{\mathrm{c}}$ & 9.59 \\
\hline \% body weight & 2.3 & 2.5 & 2.4 & 2.1 & \\
\hline \multicolumn{6}{|l|}{ Apparent digestibility,\% } \\
\hline Organic matter & $55.6^{\mathrm{b}}$ & $56.8^{b}$ & $59.9^{\circ}$ & $59.6^{2}$ & 0.55 \\
\hline Crude protein & $51.5^{\mathrm{b}}$ & $52.3^{\mathrm{b}}$ & $57.3^{\circ}$ & $58.1^{2}$ & 0.88 \\
\hline Euher extract & $38.7^{c}$ & $51.9^{b}$ & $68.2^{2}$ & $76.1^{2}$ & 4.37 \\
\hline Crude fiber & $53.3^{\mathrm{b}}$ & $53.3^{\mathrm{b}}$ & $60.8^{b}$ & $67.3^{\circ}$ & 0.49 \\
\hline Nitrogen free extract & $53.5^{\mathrm{b}}$ & $56.1^{2}$ & $56.7^{2}$ & $56.9^{a}$ & 0.41 \\
\hline \multicolumn{6}{|l|}{ Nitrogen Utilization: } \\
\hline Nitrogen intake, g/day & $10.1^{\mathrm{e}}$ & $12.9^{b}$ & $13.8^{\mathrm{a}}$ & $13.0^{\mathrm{ab}}$ & 0.29 \\
\hline \multicolumn{6}{|l|}{ Nitrogen excretion $g /$ day: } \\
\hline Fecal & $3.85^{\circ}$ & $4.55^{b}$ & $5.40^{\circ}$ & $5.12^{\mathrm{a}}$ & 0.18 \\
\hline Urine & $5.64^{\mathrm{b}}$ & $6.71^{b}$ & $8.35^{\circ}$ & $8.97^{\circ}$ & 0.40 \\
\hline Total & 9.49 & 11.26 & 13.75 & 14.09 & \\
\hline \multicolumn{6}{|l|}{ Nitrogen retention: } \\
\hline g/day & $0.61^{b}$ & $1.64^{2}$ & $0.05^{\mathrm{c}}$ & $-1.09^{d}$ & 0.18 \\
\hline$\%$ of $N$ intake & $6.04^{b}$ & $12.70^{\mathrm{a}}$ & $0.36^{\mathrm{c}}$ & $-8.38^{d}$ & 1.34 \\
\hline$\%$ of $\mathrm{N}$ absorbed & $9.80^{\mathrm{b}}$ & $19.70^{2}$ & $0.59^{\circ}$ & $-13.8^{d}$ & 2.10 \\
\hline
\end{tabular}

$a, b, c, d:$ Means ( 4 animals each treatment) the same raw with different superscript differ $(\mathrm{P}<0.01)$.

Ruminal fluid and blood metabolites

some ruminal fluid and blood metabolites are summarized in Table 5. Ruminal pH values increased $(P<0.01)$ as the proportions of poultry manure increased in ensiled diets. Feeding silages containing higher proportions of poultry manure ( $\mathrm{T} 3$ and $\mathrm{T} 4$ ) resulted in higher $(P<0.01)$ ruminal Ammonia-N. It might due to its high content of non-protein nitrogen (NPN). It was also, reflected on blood urea-nitrogen (BUN) concentration which was doubled for sheep fed 50:50 BGH-PM silage (T4) compared to those fed the control diet (T1) as shown in Table 5 (16.3 Vs $8.79 \mathrm{mg} / \mathrm{dl})$. The low ruminal ammonia-N and BUN concentrations with animals fed bermudagrass hay only (T1) might be related to their low protein intake 
(Table 4). Similar trends were reported by salyor and Long (1974); Richter and Kalmbacher, (1980), and El Bedawy et al. (1989). Generally, the results showed that the nitrogen in ensiled poultry manure was utilized efficiently by sheep. The total VFA's concentrations were higher $(P<0.01)$ for sheep in $T 3$ and $T 4$ compared to those in $\mathrm{T} 1$ and $\mathrm{T} 2$. The higher ruminal propionate by sheep fed BGH-PM silages, particularly those in T4, might due to the low roughage levels of their silages (El-Bedawy et al., 1989).

Table 5. Rumen and blood metabolites of sheep fed bermudagrass hay ensiled with poultry manure (BGH-PM silages)

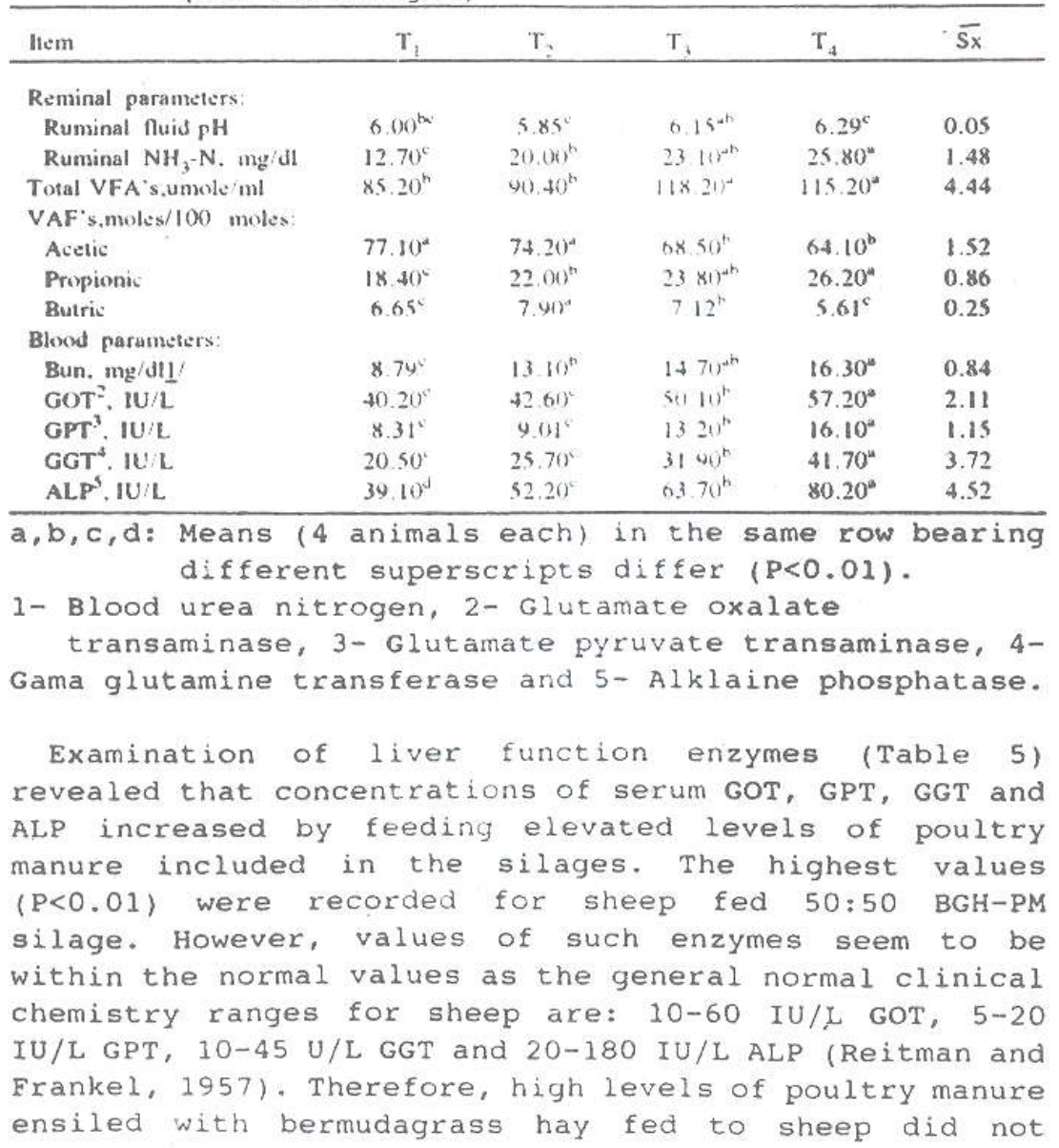


exhibit clinical or sub-clinical effects. The results concluded that feeding ensiled poultry manure to sheep was safe which agree well with those reported by $\mathrm{Z}$ indell et al. (1979) and Fontenot (1983).

In conclusion, judging from the previous results, ensiling bermudagrass hay with poultry manure at level of 70:30 could be used efficiently and suggested to be a good diet for sheep without any harmeful effect on animals.

\section{REFERENCES}

Abdemawla, S.M., J.P. Fontenot and M.A. El Ashry, 1987. Composted, deepstacked, and ensiled boiler litter in sheep diets: Chemical composition and nutrintive vlaue study. Virginia Tech. Livstock Report, VPI, USA, pp. 127-132.

Amercian Public Health Assoication, 1978. Standard. methods for the examination of dairy products. 14th ed. 10105, Eighteenth St. N.W., Washington.

A.O.C.A. 1975. Official methods of analysis. Association of Official Agricultural. Chemists, $12 \underline{t h}$ Ed. Washngton, DC.

Attia-Ismail, S.A., 1992. Comparative study on the effect of including poultry wastes on the performance of lactating buffaloes and goats. Ph.D. Thesis, Ain shams Univ., Cairo, Egypt.

Barnett, A.J.G. and R.L. Reid, 1956. Studies on the production of volatile fatty acids from grass by rumen liquor in an artifical rumen. 1. Volatile fatty acids production from grass. J. Agric. Sci., 48: $315-321$.

Caswell, L.F., J.P. Fontenot, and K.E. Webb, Jr., 1978. Fermentation and utilization of broiler litter ensiled at different moisture levels. J. Anim. Sci., 46: 547-561.

Coulombe, J.J. and L. Larreau, 1963. A new semi-micro method for colorimetric determination of urea. Clin. Chem., 9: 120-129.

Duncan, D.B., 1955. Multiple range and multiple. F Tests. Biometrics. 11:1.

El-Bedawy, T.M., T.T. EL Gallad, E.A. Gihad, A.M. Abd El Gawad, and A.M. Hanafy, 1989. Ureated barley and poultry manure in concentrates for small ruminatns in the valley and desert of Egypt. J. Agric. Sci., 
Mansoura Univ., 214: 2350-2362.

El Shaer, H.M., H.S. Khamis, O.A. Salem, M.F.A. Farid, and A.S. Shalaby, 1990. Palatability and nutritional evaluation of the broiler litter silage using goats and sheep. Proc. Int. Goat Production Symp., Oct. 22-26, 1990, Tallahassee, Florida, USA, pp. 151-154-1534.

El Shaer, H.M., H.M. Kandil, and H.S. Kamis, 1991. Salt marsh plant ensiled with dried broiler litter as a feedstuff for sheep and goats. J. Agric. Sci., Mansoura Univ. 16: 1524.

Fontenot, J.P., 1983. Utilization of animal wastes by feeding-special emphasis on United states of America. proc. of An Inter. Symp., Wageningen, Netherlands, 30 Nov. - 2 Dec. 1983, pp. 12-21.

Fontenot, J.P., K.E. Webb, Jr., B.W. Harmon, R.E. Tucker and W.E.C. Moore, 1971. Stdies of processing, nutritional value and palatability of broiler litter for ruminants. Proc. Intel. System on livestock wastes. A.S.A.E. Publ. Proc-27: 301-304.

Harmon, B.W.; J.P. Fontent, and K.E. Webb, Jr., 1974. Effect of processing method of broiler litter on nitrogen utilization by lambs. J. Anim. Sci., $39(5): 942-946$.

Harmon, B.W.; J.P. Fontenot, and K.E. Webb, Jr., 1975. Ensiled broiler litter and corn forage. I. Fermentation characteristics. J. Anim. Sci., 40: 144-155.

Kwak, W., J.P. Fontenot, and J.H. Herbein, 1987. Nutrient utilizaion from broiler litter processed by different methods. Virginai Tech. Livestock Report, VPI, USA, pp. 54-58.

McCaskey, T.A. and J.B. Martin, Jr., 1988. Evaluation of a process of improved quality and microbial saftey of broiler litter. Biological Wastes, 25: 209-218.

Oliphant, J.M., 1974. Feeding dired poultry waste for intensive beaf production. J. Anim. Prod. 18: 211-217.

Reitman, S. and S. Frankel, 1957. A colorimetric method for the determination of glutamic-oxaloacetic and glutamic pyruvate transaminase. Amer. J. Clin. Path. 28: 56-61.

Richter, M.F. and R.S. Kalmbacher, 1980. Nutrient metabolism and quality of corn and sorghum silages made with caged layer manure.Proc. Soil and crop 
Sci. Soc. of Florida, 39: 125-127.

Samuels, W.A., J.P. Fontenot, W.D. Lamm, and K.E. Webb, Jr., 1980. Fermentation characteristics of caged layer waste ensiled with sugar-cane bagasse. VPI \& SU Res. Div. Rep. 156: 189-194.

Saylor, W.W. and T.A. Long, 1974. Laboratory evalution of ensiled poultry waste. J. Anim. Sci. 39: 139 (Abst.).

Schewartz, H.M. and C.A. Schoeman, 1964. Utilization of urea by sheep. 1. Rates of breakdown of urea and carbohydrates in vivo and in vitro. J. Agric. Sci., 63: 289-291.

Shannon, D.W. and W.O. Brown, 1969. Losses of energy and nitrogen on drying poultry excerta. Poultry science. $48: 41-43$.

snedecor, G.W. and W.G. Cochran, 1976. Statistical Methods ( $6 \underline{t h}$ ed.) Iowa state Univ. Press. Ames., Iowa, USA.

Zindell, J.H., M.T. Yokoyama, L.R. Shull, C.J. Flegal, J.D. Krechloiel, S.D. Sleight, J.R. Anstead, and T.W. Magee, 1979. The potential hazard of livestock waste recycling. II. Evaluation of physiochemical and metabolic parametes. Res. Rep. No. 388, Mich. State Univ. Ag. Exp. Sta., Lansing, MI. 
المعاملات التصنعية لمخلفات الدواجن وتقييمها غذانيا كمكونـات علمبـة

كلاغنام

هسن محمد الشاعر - صلاح عطبية اسماعيل - همدى محمد قنديل قسم تغذية الحيوان و الدواجن، مركز بحوث الصحر اء، المطريسة، القاهرة،

اجريت هذه الدر اسات بهدف تقيبم تأثير المعاملات الحر ارية والسبلجة على الدي

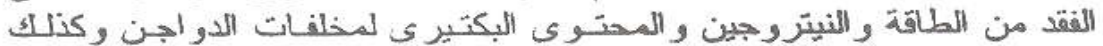

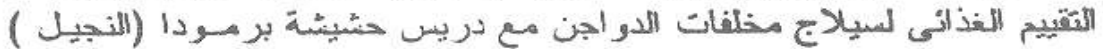

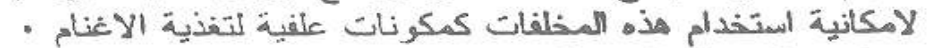

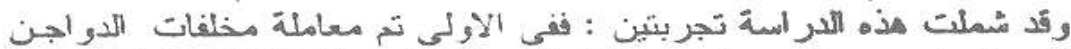

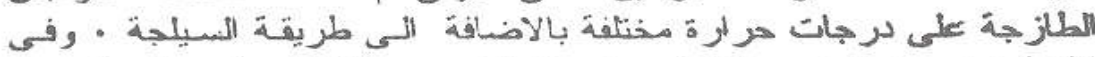

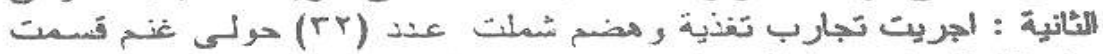

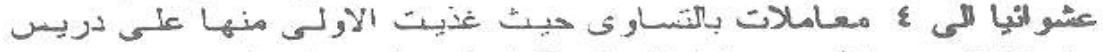

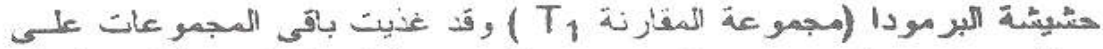

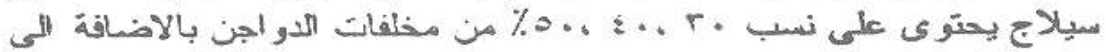

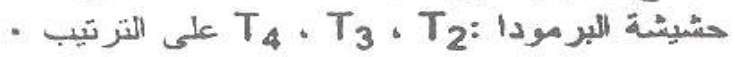

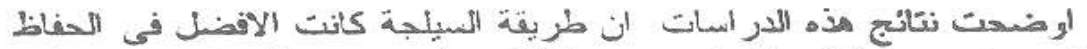

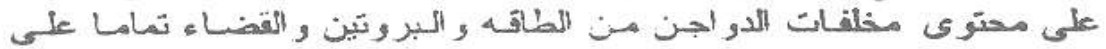

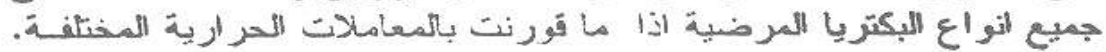

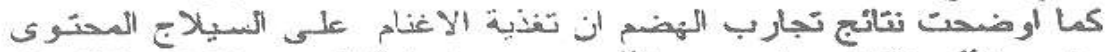

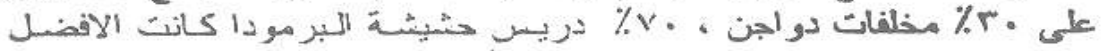

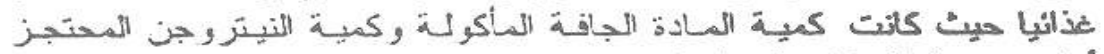

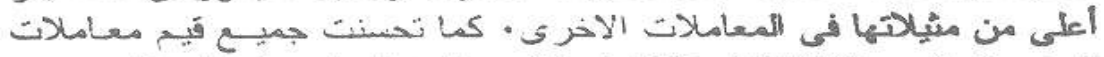

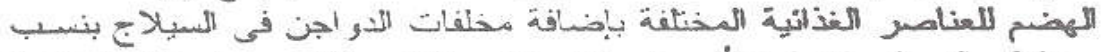

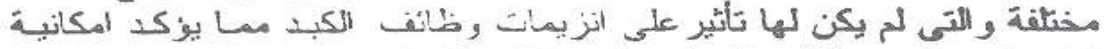

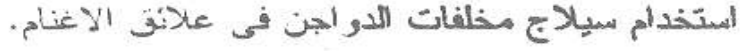

